\title{
PELAKSANAAN ADMINISTRASI KEPENDUDUKAN DAN PENCATATAN SIPIL PADA DINAS KEPENDUDUKAN DAN PENCATATAN SIPIL KABUPATEN PIDIE
}

\author{
ZULFIKAR
}

\section{Program Studi Ilmu Administrasi Negara}

\begin{abstract}
ABSTRAK
Administrasi Kependudukan merupakan suatu hal yang sangat penting dalam kehidupan masyarakat saat ini. Kependudukan selalu bersentuhan dengan setiap aktivitas kita terutama dalam kehidupan sehari-hari diantaranya adalah saat pemilu legislatif, pemilu presiden, pilkada, mengurus surat-surat kendaraan, mengurus surat-surat tanah, dan lain sebagainya, namun kenyataan saat ini administrasi kependudukan dan pencatatan sipil Kabupaten Pidie masih tidak teratur dan tidak terdidik dengan baik.

Penelitian ini dilakukan untuk mengetahui sebagai pelaksanaan administrasi kependudukan dan pencatatan sipil pada dinas kependudukan dan pencatatan sipil Kabupaten Pidie. (1) Bagaiman pelaksanaan administrasi kependudukan dan pencatatan sipil pada dinas kependudukan dan pencatatan sipil Kabupaten Pidie. (2) Faktor-faktor apakah sebagai pendukung dan penghambat pelaksanaan administrasi kependudukan dan pencatatan sipil pada dinas kependudukan dan pencatatan sipil Kabupaten Pidie. Adapun tujuan dari penelitian ini sebagai berikut (1) Untuk mengetahui dan menganalisis pelaksanaan administrasi kependudukan dan pencatatan sipil (2) Untuk mengetahui faktor-faktor yang menjadi pendukung dan penghambat pelaksanaan administrasi kependudukan dan pencatatan sipil.

Dalam penelitian ini peneliti menggunakan pendekatan kualitatif dengan pemilihan informan dilakukan dengan sengaja(purposive sampling) pada jenis dan sumber data yang diperlukan. Teknik pengumpulan data dilakukan dengan (a) observasi (b) wawancara (d) dokumentasi, selanjutnya analisis dilakukan secara interaktif, sedangkan proses teknik analisis data dalam penelitian ini adalah analisis reduksi data, sajian data dan penarikan kesimpulan.

Hasil penelitian ini bahwa para pegawai dinas kependudukan dan pencatatan sipil telah memberikan pelayanan yang maksimal kepada masyarakan, Namun disisi lain peneliti masih melihat terdapat beberapa hambatan-hambatan yang terjadi dalam proses pelaksanaan adalah tidak maksimalnya jaringan online yang mengakibatkan terhambatnya penerbitan data dan kurang efektifnya sosialisasi e-KTP mengakibatkan banyak masyarakat belum memiliki e-KTP di Kabupaten Pidie,

Berdasarkan penelitian diatas dapat disimpulkan bahwa perlunya perhatian pemerintah Kabupaten Pidie terhadap jaringan online pada dinas kependudukan dan pencatatan sipil yang memadai untuk kelangsungan pelaksanaan administrasi kependudukan dan pencatatan sipil.
\end{abstract}

Kata Kunci: Administrasi Kependudukan

\section{Latar Belakang}

AdministrasiAdministrasi

kependudukan merupakan kegiatan yang kompleks karena melibatkan banyak instansi dan kepentingan. Dari beberapa instansi yang terkait, Departemen Dalam Negeri merupakan leading sector dalam urusan kependudukan. Kebijakan departemen inilah yang mereflesikan kebijakan administrasi kependudukandi Indonesia. Selain itu, implementasikebijakan ini dapat dilihat dari penyelenggaraan administrasi kependudukan pada Pemerintah Daerah baik Provinsi maupun Kabupaten/Kota yang merupakan instansi yang berada di 
bawahkoordinasi Departemen Dalam Negeri.

Pemamfaatan kepastian data sangatlah berguna bagi masyarakat dangan keaslian data yang dimiiliki oleh setiap orang maka kebebasan dan kepatuhan terhadap negara akan dijunjung tinggi.

Kependudukan sebenarnya merupakan basis utama dan fokus dari segala persoalan. Penduduk yang baik akan melahirkan sumber daya manusia (SDM) yang baik pula. Jumlah penduduk yang besar tetap akan berarti bila sebagian besar dari mereka mampu berkarya dan berpartisipasi dalam pembangunan. Sebaliknya jumlah penduduk yang besar akan menambah beban ekonomi dan pembangunan, bila tidak dapat diberdayakan secara baik.

Gagasan menyusun suatu sistem administrasi yang menyangkut seluruh masalah kependudukan yang meliputi pendaftaran penduduk, pencatatan sipil, pengelolaan data informasi kependudukan, patut menjadi perhatian untuk mewujudkannya, Karena sampai saat ini, peraturan perundang-undangan yang mendukungnya masih terpisah-pisah, berjalan sendiri-sendiri tanpa ada kaitan satu dengan lainnya. Perwujudan suatu sistem memang sangat didambakan oleh masyarakat. Bahkan sebagai ciri dari penyelenggaraan negara yang modern khususnya bidang pelayanan masyarakat.

Manfaat yang diraih dalam penyelenggaraan Program Pelayanan Administrasi Perkantoran adalah terlaksananyakegiatanpelayanan administrasi perkantoransehingga menunjang dan memperlancarpelaksanaan pekerjaanserta tersedianya sarana dan prasarana pelayanan administrasi perkantoran yang mendukung pelaksaan pelayanan umum pemerintahan dan meningkatkan pelayanan kepada masyarakat.

Undang-undang Nomor 23 Tahun 2006 tentang Administrasi Kependudukan dan Peraturan Pemerintah Nomor 37 Tahun 2007 tentang Pelaksanaan Undang-undang Nomor 23 Tahun 2006 tentang menjamin hak seorang/kelompok penganut Penghayat Kepercayaan Terhadap Tuhan Yang Maha Esa untuk mendapatkan hak-hak administrasi kependudukanseperti pencantuman kepercayaan dalam KTP, akta kelahiran, perkawinan dan dokumen kematian yang dijamin dalam Undangundang Nomor 23 Tahun 2006 tentang Administrasi kependudukan. Ada juga payung hukum lain yakni Peraturan Presiden (Perpres) Nomor 25 Tahun 2008 tentang Persyaratan dan Tata Cara Pendaftaran Penduduk dan Catatan Sipil. Dan ada juga Qanun Otonomi Daerah Kabupaten Pidie Nomor 4 Tahun 2011 tentang Penyelenggara Administrasi Kependudukan.

Dariuraiandiatas,peneliti memandang perluuntuk membahas dan mengkaji lebih dalam mengenai bagaimana pelaksanaan administrsi kependudukan dan catatan sipil pada di Dinas Kependudukan dan Pencatatan Sipil Kabupaten Pidie.

\section{Identifikasi Masalah}

Berdasarkan latar belakang permasalahan diatas maka rumusan permasalahan sebagai berikut.

1. Bagaimana Pelaksanaan administrasi kependudukan dan catatan sipil pada Dinas Kependudukan Dan Pencatatan Sipil Kabupaten Pidie.

2. Faktor-faktor apakah yang sebagai pendukung dan penghambat pelaksanaan administrasi kependudukan dan catatan sipil pada dinas kependudukan dan catatan sipil kabupaten pidie.

\section{Tujuan Penelitian}

Berdasarkanperumusanmasalah tersebut seperti yang telah diuraikan diatas, penulis dalam mengadakan penelitian tersebut memiliki tujuan sebagai berikut:

1. Untuk mengatahui dan menganalisis pelaksanaan administrasi kependudukan dan catatan sipil pada Dinas Kependudukan Dan Catatan Sipil Kabupaten Pidie.

2. Untuk mengetahui faktor-faktor yang menjadi pendukung dan penghambat pelaksanaan administrasi kependudukan 
dan catatan sipil pada dinas kependudukan dan catatan sipil Kabupaten Pidie tersebut.

\section{METODE PENELITIAN Pendekatan Penelitian}

Dalam pandangan para ahli banyak pendapat-pendapat yang disampaikan sebagaimana pandangan Moleong (2014: 6) sebagai berikut:

Penelitian kualitatif adalah penelitian yang bermaksud untuk memahami fenomena tentang apa yang dialami oleh subjek penelitian misalnya prilaku, persepsi, motivasi, tindakan dan lain-lain, secara holistic dan dengan cara deskripsi dalam bentuk kata-kata dan bahasa, pada suatu kontek khusus yang alamiah dan dengan memanfaatkan berbagai metode alamiah.

Demikian pula pendapat sebagaimana disebutkan Sugiyono (2014: 295) sebagai berikut:

Penelitian kualitatif dituntut dapat menggali data berdasarkan apa yang diucapkan, dirasakan, dan dilakukan oleh partisan atau sumber data "sebagaimana seharusnya", bukan berdasarkan apa yang dipikirkan oleh peneliti, tetapi berdasarkan sebagaimana adanya yang terjadi dilapangan yang dialami, dirasakan, dan dipikirkan oleh partisipan/sumber data.

\section{Fokus Penelitian}

Fokus penelitian merupakan pemusatan konsentrasi terhadap tujuan penelitian yang sedang dilakukan. Fokus penelitian harus diungkapkan secara eksplisit untuk mempermudah peneliti sebelum melaksanakan observasi. Fokus penelitian adalah garis besar dari penelitian, jadi observasi serta analisa hasil penelitian akan lebih terarah.

Fokus juga bisa diartikan sebagai domain tunggal atau beberapa domain yang terkait dengan situasi social, bahwa pembatasan masalah dan topik dalam penelitian kualitatif lebih didasarkan pada tingkat kepentingan, urgensi dan feasibility masalah yang akan dipecahkan, selain juga faktor keterbatasan tenaga, dana dan waktu. Suatu masalah dikatakan penting apabila masalah tersebut tidak dipecahkan melalui penelitian akan semakin menimbulkan masalah baru.

Fokus penelitian sebenarnya sangat diperlukan dalam suatu analisis agar mampu menganalisa maupun sasaran bagi peneliti yang tidak diperlukan, dengan adanya fokus penelitian akan mempermudah penelitian dalam menentukan metode dan sampai pada tahap pelaporan. Adapun yang menjadi fokus dalam penelitian ini adalah:

1. Bagaimana pelaksanaan administrasi kependudukan dan catatan sipil pada Dinas Kependudukan dan Pencatatan Sipil Kabupaten Pidie

a Pelayanan bidang pencatatan sipil?

b Sosialisasi Elektronik KTP (e-KTP)?

2. Faktor-faktor pendukung dan penghambat pelaksanaan administrasi kependudukan dan catatan sipil pada Dinas Kependudukan dan Pencatatan Sipil Kabupaten Pidie.

\section{Lokasi Penelitian}

Penelitian ini dilakukan pada dinas kependudukan dan catatan sipil Kabupaten Pidie, kantor ini berada di Jalan Banda Aceh-Medan Kecamatan Kota Sigli Kabupaten Pidie Provinsi Aceh. Relevansi metodologis, mengapa dinas kependudukan ini dipilih karena salah satu instansi pemerintah yang berhubungan langsung dangan masyarakat.

\section{Informan Penelitian}

Dalam penelitian kualitatif, yang menjadi informan penelitian utama adalah peneliti sendiri. Sebab menurut Nasution dalam Sugiyono (2008: 25) peneliti sebagai alat peka dan dapat bereaksi terhadap segala stimulus dari lingkungan yang harus diperkirakannya bermakna atau tidak bagi penelitian.

Guba dan Lincoln dalam Moleong (2014: 168) manusia sebagai instrumen penelitian mencakup ciri-ciri umum, kualitas yang diharapkan, dan kemungkinan peningkatan manusia sebagai instrumen.

Maka dalam hal ini yang menjadi informan penelitian adalah Kepala Dinas 1 
orang, Sekretaris 1 orang, Kabid pengelolaan data dan dokumen kependudukan 1 orang, Operator pelaksana 5orang Dan Masyarakat 5 orang.

\section{Teknik Pengumpulan Data}

Teknik pengumpulan data merupakan langkah yang paling utama dalam penelitian, karena tujuan utama dari penelitian adalah mendapatkan data, tanpa mengetahui teknik pengumpulan data, peneliti tidak akan mendapatkan data yang memenuhi standar data yang ditetapkan. Pendapat Sugiyono (2014: 308) Menerangkan bahwa bila dilihat dari sumber datanya, maka pengumpulan data dapat menggunakan sumber primer dan sumber sekunder. Sumber primer adalah sumber data yang langsung memberikan data kepada pengumpul data dan sumber sekunder merupakan sumber tidak langsung memberikan data kepada pengumpul data. Selanjutnya bila dilihat dari segi cara atau teknik pengumpulan data, maka teknik pengumpulan data dapat dilakukan dengan observasi (pengamatan), interview (wawancara). Kuesioner (angket), dokumentasi dan gabungan keempatnya

Berdasarkan sumber data yang diperlukan maka metode pengumpulan data dalam penelitian ini dilakukan melalui:

1) Observasi langsung, merupakan proses kegiatan keseharian dengan menggunakan panca indramata dan telinga sebagai alat bantu utama, Sehingga memperoleh informasi dan data dari tangan pertama dengan mengamati orang dan tempat pada saat dilakukan penelitian, Sambil melakukan pengamatan, peneliti ikut melakukan apa yang dikerjakan oleh sumber data dan ikut merasakan suka dukanya. Maka data yang diperoleh akan lebih lengkap, tajam dan sampai mengetahui pada tingkat makna dari setiap perilaku yang tampak.

2) Wawancara, merupakan teknik pengumpulan data untuk menemukan permasalahan yang harus diteliti. Wawancara (interview) dapat dipandang sebagai metode pengumpulan data dengan jalan jawab sepihak, yang dikerjakan dengan sistematis dan berlandaskan kepada tujuan penelitian.

3) Studi Dokumentasi

Pendapat Sugiyono, (2014: 326) dokumen merupakan catatan peristiwa yang sudah berlalu, bisa berbentuk tulisan, gambar atau karya-karya monumental dari seseorang atau suatu peristiwa. Studi dokumen merupakan pelengkap dari penggunaan metode observasi dan wawancara dalam penelitian kualitatif.

\section{HASIL}

\section{Pelaksanaan Administrasi Kependudukan Dan Pencatatan Sipil.}

1. Pelaksanaan Administrasi

Kependudukan Dan Pencatatan Sipil.

Salah satu kegiatan pelayanan pemerintah untuk mengukur kinerja mengacu pada penilaian kinerja secara tidak langsung yaitu hal-hal yang sifatnya hanya merupakan indikasi-indikasi kinerja. Indikator kinerja dan ukuran kinerja ini sangat dibutuhkan untuk menilai tingkat ketercapaian tujuan, sasaran dan strategi. Konsep produktivitas tidak hanya mengukur tingkat efisien, tetapi juga mengukur efektivitas pelayanan. produktivitas pada umumnya dipahami sebagai rasio antara input dengan output, Dalam hal ini Dinas Kependudukan dan Pencatatan Sipil Kabupaten Pidie dapat dikatakan sudah membaik dilihat dari hasil input dan output yang meningkat dari tahun sebelumnya mencapai rata-rata 300 sampai 400 dokumen yang dicetak setiap hari kerja selama lima hari. Namun terdapat sedikit masalah yaitu ketidak telitian para operator pelangsana sehingga masih terdapat data masyarakat tang salah.

2. Sosialisasi Elektronik KTP (e-KTP)?

Kartu Tanda Penduduk elektronik (eKTP) dilatar belakangi oleh sistem pembuatan KTP konvensional di Indonesia yang memungkinkan seseorang dapat memiliki lebih dari satu KTP yang disebabkan belum adanya basis sistem pelayanan terpadu yang menghimpun data penduduk dari seluruh Indonesia. 
Proses sosialisasi/pembelajaran berlangsung secara bertahap, perlahan tapi pasti dan berkesinambungan. Pada awalnya, proses itu berlangsung dari pemerintah pusat, pemerintah provinsi dankabupaten pidie sampai kepada tingkat kecamatan dan tingkat gampong-gampong.

Pencapaiantujuan pelaksanaan perekaman data e-KTP di Kabupaten Pidie sebagai suatu proses dilalui mulai tahapan perencanaan hingga pelaksanaan. Masingmasing tahapan ini perlu dilakukan komunikasi yang baik guna koordinasi masing-masing bagian bisa bekerja secara optimal. Terkait dengan tahapan perencanaan pelaksanaan perekaman data program eKTP di Kabupaten Pidie sudah dijalan oleh pihak Dinas Kependudukan dan Pencatatan Sipil. Dinas kependudukan dan pencatatan sipil Kabupaten Pidie telah memberikan pelayanan yang sangat baik kepada masyarakat yang membutuhkan pelayanan dan produktivitas sudah meningkat dari tahun sebelumnya hal ini dapat di lihat dari hasil output data yang dikeluarkan dapun kelemahan yang dimiliki oleh dinas kependudukan dan pencatatan sipil Kabupaten Pidie adalah pada sosialisasi e-KTP yang tidak merata dan kurang memadai ketingkat pedalaman hal ini berpengaruh terhadap keakuratan data penduduk yang masih tidak terkoordinir pada dinas kependudukandan pencatatan sipil kabupaten pidie hal ini dapat dibenarkan dengan data informasi perkembangan kependudukan di Kabupaten Pidie berjumlah 436.024 jiwa dan yang wajib memilik e-KTP sebanyak 307.487 jiwa dan yang belum memiliki e-KTP sebanyak 50.655 jiwa.

3. Faktor-faktor apakah yang sebagai pendukung dan penghambat pelaksanaan administrasi kependudukan dan catatan sipil pada dinas kependudukan dan catatan sipil kabupaten pidie.

a Faktor pendukung

Berkaitan dengan perkembangan jumlah penduduk. administrasi kependudukan berperan penting dalam memberikan jaminan kepastian hukum dan perlindungan terhadap hak-hak individu penduduk. Perlindungan tersebut berupa pelayanan publik melalui penerbitan dokumen kependudukan seperti Nomor Induk Kependudukan (NIK), Kartu Tanda Penduduk (KTP) Kartu Keluarga (KK), Akta Kelahiran. Dan Sumber daya manusia yang sering kali masih belum sejalan dengan keinginan organisasi. Sementara keselarasan dalam mengelola sumber daya manusia menjadi faktor utama kesuksesan jalannya sebuah organisasi. Meskipun kemampuan sumber daya manusia bersifat fleksibel, menjadi poin yang digaris bawahi

b Faktor penghambat

Sarana prasarana sangatlah di butuk dalam melakukan sebuah kegiatan. Dinas kependudukan kabupaten pidie dalam hal ini banyak sekali kendala. Sarana komputer yang terbatas. Padahal dukungan sarana komputer untuk mempercepat proses penyelesaian penyelesaian pelayanan publik sangat diperlukan dan begitu pun dengan peralatan-peralatan kantor yang masih sangat kurang sehingga menghambat kinerja pegawai.

Keterbatasan sarana prasarana dalam suatu perkantoran menjadi salah satu faktor yang memilukan karena dengan keterbatasan ini akan berakibat terhambatnya pelaksanan administrasi kependudukan dan pencatatan sipil pada dinas kependudukan dan pencatatan sipil kabupaten pidie.

\section{Pembahasan}

1. PelaksanaanAdministrasi Kependudukan dan Pencatatan Sipil

a Pelayanan Bidang Pencatatan Sipil

Pelayanan bidang pencatatan sipil dapat dilihat dari Produktivitas pelayanan pencatatan sipil yang sudah meningkat dari tahun sebelumnya hal ini dapat kita lihat dari hasil output data yang dikeluarkan. Peningkatan ini akan lebih sempurna jika sarana dan prasarana dapat di penuhi akan tetapi Dinas Kependudukan dan Pencatatan 
Sipil masih memiliki kelemahan terhadap kualitas data yang dikeluarkan di sebabkan karena ketidak jelinya petugas pelaksana kegiatan sehingga masih ada data yang salah di karenakan kemampuan yang dimiliki tidak di implementasikan dengan baik.

Temuan 1: Perlunya kejelian petugas terhadap kualitas data yang hendak dikeluarkan agar data yang di dapatkan masyarakat tidak mempunyai kesalahan.

b Sosialisasi Elektronik KTP (e-KTP)?

Sosialisasi e-KTP yang tidak merata dan kurang memadai ketingkat pedalaman hal ini berpengaruh terhadap keakuratan data penduduk yang masih tidak terkoordinir pada dinas kependudukandan pencatatan sipil kabupaten pidie hal ini dapat dibenarkan dengan data informasi perkembangan kependudukan di Kabupaten Pidie berjumlah 436.024 jiwa dan yang wajib memilik e-KTP sebanyak 307.487 jiwa dan yang belum memiliki e-KTP sebanyak 50.655 jiwa.

Temuan 2: Sosialisasi e-KTP belum berjalan maksimal disebabkan tidak efektifnya sosialisasi hingga ketingkat gamponggampong di kabupaten pidie

\section{Kesimpulan}

Dalam penelian yang judul pelaksanaan administrasi kependudukan dan pencatatan sipil pada dinas kependuduukan dan pencatatan sipil kabupaten pidie dapat menarik kesimpulan sebagai berikut:

1. Pelaksanaan administrasi kependudukan dan pencatatan sipil kabupaten pidie belum terlaksana dengan baik dilihat dari segi kualitas data yang di keluarkan dan sosialisai e-KTP yang dilakukan belum maksimal dan lemahnya jaringan mengakibatkan terhambatnya perekaman atau pembuatan e-KTP di tingkat kecamatan.

2. Penerapan sumber daya manusia yang baik harus didasarkan dari kemampuan yang dimilikinya baik secara pendidikan maupun pengalaman agar sistem informasi administrasi kependudukan dapat di operasikan dengan sempurna.

\section{Daftar pustaka}

Buku

Moleong, Lexy. (2014). Metode Penelitian Kualitatif. Bandung: PT.Remaja Rosdakarya

Sugiyono. (2008). Metode Penelitian Kuantitatif Kualitatif dan R\&D. Bandung: Alfabeta.

............(2014). Metode Penelitian Kuantitatif Kualitatif dan R\&D. Bandung: Alfabeta.

Dokumen

Undang-undang Nomor 23 Tahun 2006 Tentang Administrasi Kependudukan (Amikduk).

Undang-Undang Nomor. 25 Tahun 2009 Tentang Pelayanan Public.

Keputusan Menteri Pendayagunaan Aparatur Negara Nomor.63 Tahun 2003 Tentang Pedoman Umum Penyelenggaraan Pelayanan Public.

Qanun Kabupaten Pidie Nomor 4 Tahun 2011 Tentang Penyelenggara

Administrasi Kependudukan. 